\title{
CEsifo \\ WORKING

\section{The Implications of the New Silk Road Railways on Local Development}

Ling Fang, Martin Kleimann, Yuan Li, Hans-Jörg Schmerer 


\section{Impressum:}

CESifo Working Papers

ISSN 2364-1428 (electronic version)

Publisher and distributor: Munich Society for the Promotion of Economic Research - CESifo

$\mathrm{GmbH}$

The international platform of Ludwigs-Maximilians University's Center for Economic Studies and the ifo Institute

Poschingerstr. 5, 81679 Munich, Germany

Telephone +49 (0)89 2180-2740, Telefax +49 (0)89 2180-17845, email office@cesifo.de

Editor: Clemens Fuest

www.cesifo-group.org/wp

An electronic version of the paper may be downloaded

- from the SSRN website: www.SSRN.com

- from the RePEc website: www.RePEc.org

- from the CESifo website: www.CESifo-group.org/wp 


\title{
The Implications of the New Silk Road Railways on Local Development
}

\begin{abstract}
This paper studies regional treatment effects of infrastructure projects on economic growth, employment and intermodal transport volumes. The recent Belt and Road Initiative provides an experiment that can be evaluated using matching econometrics. Our results show that the establishment of a new railway connection is not systematically associated with short-run economic growth. However, it spurs employment and road freight by stimulating intermodal transport.
\end{abstract}

JEL-Codes: F000, F150, F190.

Keywords: infrastructure, development, trade.

$\begin{array}{cc}\text { Ling Fang } & \text { Martin Kleimann } \\ \text { University of Duisburg-Essen } & \text { University of Duisburg-Essen } \\ \text { Mercator School of Management \& Institute of } & \text { Mercator School of Management \& Institute of } \\ \text { East Asian Studies / Duisburg / Germany } & \text { East Asian Studies / Duisburg / Germany } \\ \text { ling.fang@uni-due.de } & \text { martin.kleimann@uni-due.de } \\ \text { Yuan Li } & \text { Hans-Jörg Schmerer } \\ \text { University of Duisburg-Essen } & \text { FernUniversität in Hagen } \\ \text { Mercator School of Management \& Institute of } & \text { Faculty of Business Administration and } \\ \text { East Asian Studies / Duisburg / Germany } & \text { Economics / Hagen / Germany } \\ \text { yuan.li@uni-due.de } & \text { Hans-Joerg.Schmerer@fernuni-hagen.de }\end{array}$

October 14, 2019

We would like to thank the participants of The 11th CEA (Europe) and 30th CEA (UK) Annual Conference in Stockholm, The East Asia Forum: Economic (Dis)integration in London, The Fourth International Forum on the "New Silk Road" and Sino-European Cooperation in Duisburg, and The Second International Forum on Belt and Road \& Global Governance in Shanghai for their useful comments. 


\section{Introduction}

As a signature project of the Belt and Road Initiative (BRI), the so-called New Silk Road Railways or China Railway Express (CR Express) has developed rapidly since its official launch in 2013. Additional freight capacity and the growing number of linkages between cities spotted along the New Silk Road are supposed to stimulate bilateral trade between countries connected by this initiative. However, the rapid development of the CR Express also provoked a lively debate in the media. Advocates of the project stress the potential gains from intensified trade, whereas detractors are more concerned about hidden consequences for the economy and a higher dependency on China (Holland 2017; Shepard 2018).

There is also a growing number of academic studies dealing with potential effects of BRI (Thurer et al. 2018; Ito 2019), Yet most of the existing studies focus either on the impact on international trade (Soyres et al. 2018; Herrero and Xu 2017) or the impact on investment (M. X. Chen and Lin 2018). The impact of the CR Express, in particular, has been tapped only by a very few scholars (Vinokurov and Tsukarev 2018;Y. Li, Bolton, and Westphal 2018).

This paper provides an analysis of potential effects of the establishment of the CR Express on real economic outcomes. Infrastructure projects as the CR Express are crucial development drivers. Improvements in infrastructure usually generate higher aggregated surplus and it may reduce inequality across regions. The CR Express crosses a significant number of EU countries that differ with respect to economic size and domestic conditions. These different characteristics should be associated with different patterns of comparative advantage across the integrated countries. Thus, its overall economic impact may be ambiguous due to opposing region-specific effects. Some regions or sectors of the economy may benefit from improved trade and investment opportunities, while others may suffer from heightened competition. But is the net effect of the CR Express on 
the local economy positive, negative or even zero? Does the introduction of CR Express spur economic growth in every segment of the economy or is it associated with diversion effects between sectors and regions? A better understanding of the overall impact as well as the sector-specific impacts in the economy provides an important foundation for both the academic and the political debates on this ambitious project.

The CR Express posses some unique features that complicate the evaluation of this project. Most importantly, little direct investments into the creation of new infrastructure were made for establishing the new routes ${ }^{1}$. Instead, the CR Express operates using the existing railway infrastructure. Thus, a cost benefit analysis (CBA), which is a well-accepted method for analyzing massive infrastructure projects, is not appropriate for the analysis of the question raised in our paper. At first glance, the difference in difference estimator seems to be a better choice but the fuzzy starting point of the CR Express raises serious doubts about the validity of the assumptions needed for this kind of treatment analysis. Moreover, the dynamics of the infrastructure project must be taken into consideration when choosing the right estimation framework.

This paper uses matching econometrics to tackle these technical problems in the analysis of the treatment effect of CR Express on the terminal cities in Europe. Three different tests are analyzed in detail: The economic effect is estimated through the treatment effects on per capita gross value-added, the social welfare effect is estimated by analyzing employment effects associated with the infrastructure project and a test for connectivity effects is implemented by an assessment of the treatment effects on road freight.

We set up a baseline model with fixed effects to explore the panel structure of the data. Causality of the results is tested using Mahalanobis distance matching (MDM) and Coarsened Exact Matching (CEM). We also investigate potential spill-over effects on

\footnotetext{
${ }^{1}$ Direct investment on building new railway lines under the BRI do exist, however, they are not related to the CR Express and, most of them, are still at the planning stage or have just started the construction work. One example is the Hungary-Serbia railway which is $350 \mathrm{~km}$ in total and its first segment $(34.5 \mathrm{~km})$ construction just started in 2017 (http://www.xinhuanet.com//english/2017-11/29/c_136787298.htm).
} 
neighboring regions. We expect that the effect is strongest in regions with direct access to the railroad, still significant in regions lying within a catchment area surrounding the core region and insignificant in regions far away from the railway. Besides, evidence for spatial spillover effects can be interpreted as a better integration of local goods market (H. Li and Z. Li 2013).

However, the treatment group is rather small. Thus, the effect may be insignificant at the aggregated level. The analysis on the aggregated level is complemented by a sector-specific analysis of the treatment effects. Finally, we run a placebo test as a robustness check. Our analysis builds on Eurostat data, which is constructed based on NUTS-3 level data for counties or districts with population ranging from 150 thousand to 800 thousand (European Parliament 2003) inhabitants.

The results for the three different outcome variables differ at the aggregate level. The treatment has no significant impact on per capita gross value added in the core regions. This result is not surprising as the treatment period is rather short and the changes of per capita gross value added may be emerging at a substantial lag. With respect to employment, both core and neighboring regions show a significant growth that can be attributed to the treatment. Similarly, the road freight results reveal positive treatment effects. Thus, there is no evidence for diversion from one transport mode to another as both transport modes are growing. At the sector level, the overall pattern of the matching results regarding per capita value added and employment are consistent with the findings for aggregated outcomes. Yet, there are still differences among industries. For per capita value added, only the public sector is negatively affected at the $10 \%$ significance level. The coefficients for regressions based upon data for the wholesale and trade sector are positive but insignificant. In terms of employment, all subsectors report significant gains but the results show that the manufacturing sector in particular is the main engine for job creation as its marginal effect even exceeds the coefficients found at the aggregated level. Moreover, the placebo test further demonstrates that 
the treatment effect dose not exist when it "should not" exist, say, when treatment is specified randomly.

In general, the results meet our expectations. At this early development stage of the CR Express, its economic contribution is not large enough to be captured by total regional economic output, neither at more aggregated nor at the industry or sector level. However, the strong effect on employment confirms that the establishment of the CR Express has some impact on local economic factors. There is a potential for future long term economic growth. The analysis suggests that the gains for the local economy are emerging mainly in the trade and manufacturing sectors. As expected, the growth effects associated with the CR Express are complements and not substitutes for road transport. The new connection promotes intermodal transport, as road freight shows a positive and significant increase.

The remainder of the paper is organized as follows. Section 2 briefly summarizes some important background information about the CR Express. Section 3 depicts the methodology, which provides a theoretical and empirical foundation for our study. Three sub-sections are included. First, three impact channels of infrastructure improvement on local economic development are studied based on in the existing theoretical literature and, based on those considerations, necessary assumptions of our study are discussed. Second, the baseline model is introduced. Third, the identification strategy with focus on the advantages of matching econometrics are discussed in detail. Section 4 elaborates on the two sources of data and the criteria for data selection. Section 5 elaborates on the results obtained from the model and robustness check. The final part, Section 6 is the Conclusion, which reveals recommendations for future studies. 


\section{Project description}

Since the launch of first CR Express between Chongqing and Duisburg in 2011, the number of trains commuting between the EU and China at a regular basis is growing fast. The overall freight capacity has expanded through heightened departure frequency and an expansion of the number of terminal cities. The time it takes for goods to arrive at the final destination by CR Express is significantly lower compared to the time it takes by ship and significantly cheaper compared to the cost of air freight. Thus, the new connections should be highly relevant for producers of time sensitive bulk goods.

\subsection{Capacity Increase}

In 2011, only 17 round trips of rail freight were running between Europe and China. This number increased by over a hundred times to 1881 by the middle of 2016 (National Development and Reform Commission of People's Republic of China 2016). In 2018, a total number of 6000 round trips have been operated, which is a year-on-year growth of 72 percent. Among all 6000 trips, 2690 were return trips from Europe to China and this number increased by 111 percent compared to the previous year. By 2019, the accumulated number of shipments exceeded 12000 round trips and the two-way transport became more balanced. A forecast predicts that by 2040 about 3 million twenty-foot equivalent unit (TEU) of cargo transportation between the EU and China would be shifted from maritime or air transport to rail freight. According to Gleave 2018 around 2-3 trains per hour are necessary to reach this ambitious goal.

Despite the fast growth of the number of trips, there is a large degree of variation among terminal cities in terms of the transport intensity. Specifically, two operation lines: Suzhou to Warsaw (Poland) and Wuhan to Pardubice (Czech Republic) both opened in 2012. Yet, in 2018, their yearly rounds were 145 (Suzhou-Warsaw) and 423 (Wuhan-Pardubice) respectively. Another connection that went into operation only one 
year ahead of them, Chongqing to Duisburg (Germany), is way more ahead at 1442 round trips (Fudan Institute of Belt and Road \& Global Governance 2019).

\subsection{Geographic Expansion}

Europe and China are connected by three different routes going through Russia (Besharati et al. 2017). The northern route from Manzhouli City to Moscow is operated by the Russian Siberian railway. The middle railway route originates at Inner Mongolia's Erenhot City and goes to Russia's Siberian Railway. The western route is from China's Longhai Railway and Lanxin Railway exiting from Alashankou Port to Moscow (Besharati et al. 2017). Currently, seven major lines are in service, for instance Chengdu to Łódź (Poland), Zhengzhou to Hamburg (Germany), and Yiwu to Madrid (Spain). Over the years, the cities having opened to CR Express were booming. By 2019, a total of 59 cities in China are connected to 49 cities in 15 European countries (Belt and Road Portal 2019). Aside from the expansion of terminal cities, the shortened transport time further narrowed the geographic distance between the EU and China. The transport time of CR Express varies among terminal cities. For instance, the earliest Sino-Europe block train Yuxinou (from Chongqing to Duisburg) runs for 13 days. While the one from Yiwu (China) to Madrid (Spain) takes 21 days (X. Chen et al. 2017). In general, CR Express halves the transport time to marine transport, which normally takes 31 days (Gleave 2018).

Nonetheless, it is also important to point out that even though the number of terminal cities of CR Express is growing rapidly over the years, it is still quite limited compared to the total number of cities in Europe.

\section{$2.3 \quad$ Trade growth}

The fast development of CR Express directly contributes to the reduction of trade cost and the growth of EU-China bilateral trade. According to EU statistics, the amount of 
goods exported from the EU to China by railway increased 42-fold from 2008 to 2018, while the amount of imported goods by railway increased by 4.6 times (Eurostat 2019). Along with the expansion of trade, the categories of transported goods by railway are expanding to electronic products, chemical products, and agricultural goods (Ma 2018). Despite the rapid traffic growth brought by CR Express, the total volume of trade by railway is still marginal at present and it is not likely that this will changes in the near future. Maritime transport still dominants. This transport mode accounts for 90 percent of China's external trade (The State Council Information Office of the People's Republic of China 2016), and around 70 percent of EU external trade (Eurostat 2017).

\subsection{Government subsidies}

CR Express has been subsidized by the government of China. The total number of subsidies is unknown due to the lack of official data but it is supposed to be large. The subsidies for each TEU of cargo transportation are estimated to lie in-between 7,500 RMB and 20,000 RMB (Global Times 2019). The competition among local governments for better trade opportunities intensifies the level of local subsidies. For instance, Chengdu subsidizes the transport costs in the form of special funds while the subsidies of Wuhan are almost as high as shipping prices (Du and Shi 2017). Supported by government subsidies, the freight cost of CR Express has been decreased dramatically, by around 60\% (Du and Shi 2017). The low transport cost creates incentives for exporters to switch transport mode from air to rail. However, a subsidy without some fixed termination date is not sustainable. It raises concerns for the insufficient market demand of railway freight and its twisting the market forces at work. In 2018, the Ministry of Finance of China advised local governments to lower their subsidies to CR Express on a yearly basis. The expected subsidies in 2020 should not exceed $30 \%$ of the total rate. 


\section{Empirical Methodology}

\subsection{Theoretical foundation}

Inspired by the work of Rietveld 1989 and Yoshino, Helble, Abidhadjaev, et al. 2018, we examine the treatment effects along three dimensions: $i$ ) overall economic outcome, namely the growth effects, $i i)$ the supply of economic input factors, namely the development effect and $i$ ii) potential connectivity effects, with an emphasis on potential redistribution or reinforcement of traffic flows of other transport modes.

\subsubsection{Growth Effects}

Hypothesis 1: The establishment of a CR Express connection has positive or no effects on local economic growth (measured by local gross value added per capita).

A new railway connection may aggravate the production of goods and services within the newly connected region. From an international trade perspective, railway connections should be most relevant for offshoring firms importing intermediate goods just in time and firms producing valuable goods sold at high prices. The advantages of the railway freight connections are best deployed by producing at arm's length to the railway hub. Incumbent firms may become more efficient due to the newly established railway connection. Moreover, less developed areas may prosper by attracting new firms settling close to the transport hub. However, only the latter effect may be significant as the production of the existing firms already adjusted to the situation before the establishment of the new train connection. Firms that are more reliant on trade with China may sort into the regions nearby the new connection hub but this process may take some time. Moreover, it is very likely that the goods transported by train to the terminal cities of the CR Express are transported further to its final destination by truck without affecting output at the location of the CR Express stops. 


\subsubsection{Development Effect}

Hypothesis 2: CR Express connections have positive/negative/no effects on local employment.

Aside from total economic output, infrastructure may also attract input factors as labor, capital or entrepreneurs. Employment, in particular, has been widely studied (Dalenberg, Partridge, and Rickman 1998). An infrastructure project creates jobs through direct (conventional expenditure effect) and indirect channels (multiplier effect). The direct channel includes design, construction, and other building related service aspects of infrastructure provision, while the indirect channel relates to derived consequences of infrastructure improvement, for instance, the industry agglomeration due to better accessibility (Bruinsma, Nijkamp, and Rietveld 1990). The better accessibility does not only increase labor demand of firms by boosting productivity, it also enhances labor supply by affecting households' migration decisions (Eberts and Stone 1992). However, improved infrastructure could also result in a substitution effect on the use of labor in the production process. It is likely that the removal of trade barriers generates employment losses in some sectors that are exposed to market competition (Button 1998; Vickerman 2008; Rietveld and Bruinsma 2012). Empirical evidence suggests that investments into infrastructure projects has the potential to stimulate growth in less densly populated areas. However, the more equally distributed growth accross regions can be associated with plummeting growth on the aggregate level due to diminishing agglomeration benefits (Haughwout 1999). The net effect of those opposing forces is difficult to predict and there is no guarantee that the net employment effect is positive.

Establishing the CR Express is not associated with the construction of new infrastructure. Thus, there are no jobs directly created for construction. Instead, the indirect effects of job creation might be either positive or negative depending on whether better accessibility leads to agglomeration or redistribution of local growth. Moreover, the additional workers are needed to handle the cargo. 


\subsubsection{Connectivity Effect}

Hypothesis 3: CR Express connections have positive effects on local road transportation (measured by local road freight volume).

Each transportation mode has its own advantages and properties, in terms of cost, speed, accessibility, frequency, safety, comfort, etc. Different modes compete and complement one another at various degrees and take several dimensions (J. Rodrigue, C. Comtois, and B. Slack 2016). Road and railway freight are the dominant transport modes for EU inland trade (Road: $75 \%$ and Rail: 18\%) (Eurostat 2018). Together they account for $10 \%$ of extra-EU trade (Eurostat 2016). The introduction of CR Express may divert traffic from road freight to railway due to better capability of moving bulk goods and value-added goods. If this is the case, then impacts brought by CR Express may not be a real growth but rather a redistribution caused by transport mode competition. However, it is possible that the CR Express activates inter-modal transport collaboration between railway and road and brings more transport volume to both rail and road freight. Combined transport, also known as intermodal transport, utilizes the advantage of different transport modes in one integrated system, thereby improving the effectiveness of the circulation of goods (J.-P. Rodrigue, Claude Comtois, and Brian Slack 2009). In fact, many logistics companies from various countries have been focusing on the development of intermodal transport along the CR Express (Council 2018).

We examine the relationship between CR Express and regional road freight transportation. The argument is that if this relationship is positive, it means the introduction of CR Express does does not crowd out road freight transportation. We expect this sign to be positive. Moreover, a positive effect of the establishment of CR Express on road freight in this region supports the reshipment hypothesis formulated in the first hypothesis. Goods carried by train may be transported on the road to its final destination without bringing direct benefits to the area connected by CR Express. 


\subsection{The baseline model}

The treatment effects are estimated by fitting the following model to the data:

$$
Y_{i t}=\beta_{0}+\beta_{1} \text { rail }_{i t}+\beta_{2} X_{i t}+\alpha_{i}+e_{i t} \quad \text { for } \quad t=1, \ldots, T \text { and } i=1, \ldots, N
$$

As a dependent variable $Y$, one of three variables is included in every regression: road freight, employment or regional per capita gross value-added. The information is observed for a specific region $i$ at year $t$. $\beta_{0}$ is a constant, rail is the treatment dummy and $X$ is a vector of controls, including dummies for ports, urban, coastal and metropolitan areas, as well as population density. Moreover, per capita gross regional product is included as an additional control in all regressions with employment and road freight on the left hand of the model. The variable $e$ denotes the error term.

To exploit the panel structure of the data, a time-invariant individual effect $\alpha$ for each region is included in the model. This fixed effects (FE) model approach allows controlling for unobserved factors that are constant over time. Including region-specific fixed effects may reduce the omitted-variable bias caused by time-invariant factors.

\subsection{Identification strategy}

Unobserved heterogeneity is accounted for by putting fixed-effects into the regression. Nevertheless, the identified effects may be spurious due to time variant effects. The difference in differences (DID) estimator can offer a solution to this problem but a natural experiment is needed to implement this estimator. The treatment must be unexpected and the outcome variables must evolve equally in both the treatment and the control regime. Moreover, some individuals must switch from the control to the treatment group. But as discussed in section 2, operation of CR express is a dynamic process which means the treatment is time-varying, and these "moving effects" will confound the treatment 
effects estimated by DID. Moreover, reversed causality between railway connectivity and economic performance is a concern in our application. The rail road assignment may affect productivity and output, but at the same time economic performance may shape the demand and supply for a CR express connection hub. This endogeneity issue would result in wrong interpretations of the causal effect of CR express on local development. Hence, it is important to address these issues.

\subsubsection{Matching}

A solution to the above issues is offered by the matching approach, for which each treated observation is matched with one or more untreated observations from the control group. The matching is executed conditional on the observed information about the included covariates. A more common approach is the Mahalanobis distance matching (MDM), which calculates the distance between treated and untreated observations based upon the Mahalanobis metric (s. Cochran and Rubin 1973):

$$
d(i, j)=(u-v)^{T} C^{-1}(u-v)
$$

The treated and untreated participants are denoted by $i$ and $j$ respectively, while $u$ and $v$ denote the values of the matching variables for both. $T$ is equal to the number of repetitions and the total amount of treated observations. At the same time, $C$ is "the sample covariance matrix of the matching variables from the full set of non-treated participants" (Guo and Fraser 2015, p.146).

Utilizing the above described approach, subsequent analysis uses the treated and matched group to examine the average treatment effect on the treated (ATET) as derived by (Abadie and Imbens 2006) and (Abadie and Imbens 2011) and implemented into Stata by (Abadie, Drukker, et al. 2004):

$$
A T E T=E\left(y_{1}-y_{0} \quad \mid \quad t=1\right)
$$


Here, ATET describes the difference in outcome variables $y_{1}-y_{0}$ for the treated, i.e. if $(t=1)$. Following the example of Abadie, Drukker, et al. 2004 we use "four matches because it offers the benefit of not relying on too little information without incorporating observations that are not sufficiently similar." (p.298)

A meaningful extension to the above depicted methodology is coarsened exact matching (CEM), which stems from the observation that most matching approaches "guarantee the matched sample size ex ante $[. .$.$] and produce some level of reduction in imbalance$ between the treated and control groups [...] only as a consequence and only sometimes" (Stefano M. Iacus, King, and Porro 2012, p.2) and also "do not check balance at all" (Stefano Maria Iacus, King, and Porro 2008, p. 7). To account for this issue CEM 'coarsens' all variables into groups with the same numerical value. Then, it applies a matching algorithm to determine the matches and ultimately discards the coarsened in favor of original values of the matched data (s. Stefano M. Iacus, King, and Porro 2012, p. 8). The matches can then be reused in a MDM specification in a way similar to equations (2a) and (2b), while, at the same time, ensuring sufficient balance ${ }^{3}$ between the treated and matched sample.

\subsubsection{Testing neighbor area spillover effects}

Another way to identify the causal effect is exploring the cross-region spillover effects of the railway connection. Due to network externalities of the transportation system, a railway connection in one area could affect adjacent areas. Hence, we include the neighboring areas of the treated core regions as extended treatment group or "larger area", which contains the original destinations as well as their immediate surroundings. A successful test on spillover effects would be an indication of causality as the economic

\footnotetext{
${ }^{2}$ At the same time, it has to be noted that "like all smoothing parameters, the final inference can depend on the choice of the number of matches" (Abadie, Drukker, et al. 2004, p.298).

${ }^{3}$ The exact balancing conditions for all matching estimations have been added to the Appendix.
} 
activities in neighbor regions are less affected by railway connection than the activities in the core regions. The aggregated impact might be even larger in direct treatment regions. This approach is similar to that used by H. Li and Z. Li (2013), which estimates the spatial spillover of road networks in China.

\section{Data}

To identify the local development impact of the CR express, two main sources of data have been used. Firstly, to identify the newly introduced rail connections as the treatment, the official "China Railway Express Development Plan",which records the point of departure, the terminal station, as well as the date of initial operation has been utilized (Table 1). The CR Express development plan was set up by the leading group on advancing the Belt and Road Initiative, the highest coordination and decision-making body on the Belt and Road Initiative of the Chinese government. Due to the dynamic nature of the project, additional connections have been introduced at later stages.

Table 1: Observed train routes

\begin{tabular}{|l|l|l|l|}
\hline Train route & Initial date of operation & Destination Country & Distance $(\mathrm{km})$ \\
\hline Chongqing-Duisburg & July 2011 & Germany & 11179 \\
Wuhan- Pardubice & October 2012 & Czech Republic & 10100 \\
Suzhou-Warsaw & November 2012 & Poland & 11200 \\
Chengdu-Lodz & April 2013 & Poland & 10800 \\
Zhengzhou- Hamburg & July 2013 & Germany & 10214 \\
Yiwu-Madrid & November 2014 & Spain & 13000 \\
Changsha-Duisburg & October 2014 & Germany & 11905 \\
Malaszewicze (transit hub) & & Poland & \\
\hline
\end{tabular}

Secondly, the main body of data, including the three dependent variables, as well as a number of controls has been extracted from Eurostat, the statistical office of the European Union (EU). It makes use of the Nomenclature of territorial units for statistics (NUTS) classification ${ }^{4}$. In this specific case, data is utilized at the NUTS-3 level, which

\footnotetext{
${ }^{4}$ NUTS is characterized as "a hierarchical system for dividing up the economic territory of the EU
} 
is at the finest degree of fragmentation and contains "small regions for specific diagnoses" (Eurostat 2019) $)^{5}$

For the purpose of further analysis, data starting from 2008 has been extracted, which is five years before official BRI promulgation. Utilizing a substantially large sample in terms temporal coverage is pertinent, especially when trying to examine the cut-off impact after treatment. We have extracted data until the latest available period, the year of 2017, thus the time dimension of the examined panel spans ten years.

Figure 1: Mean values of dependent variables
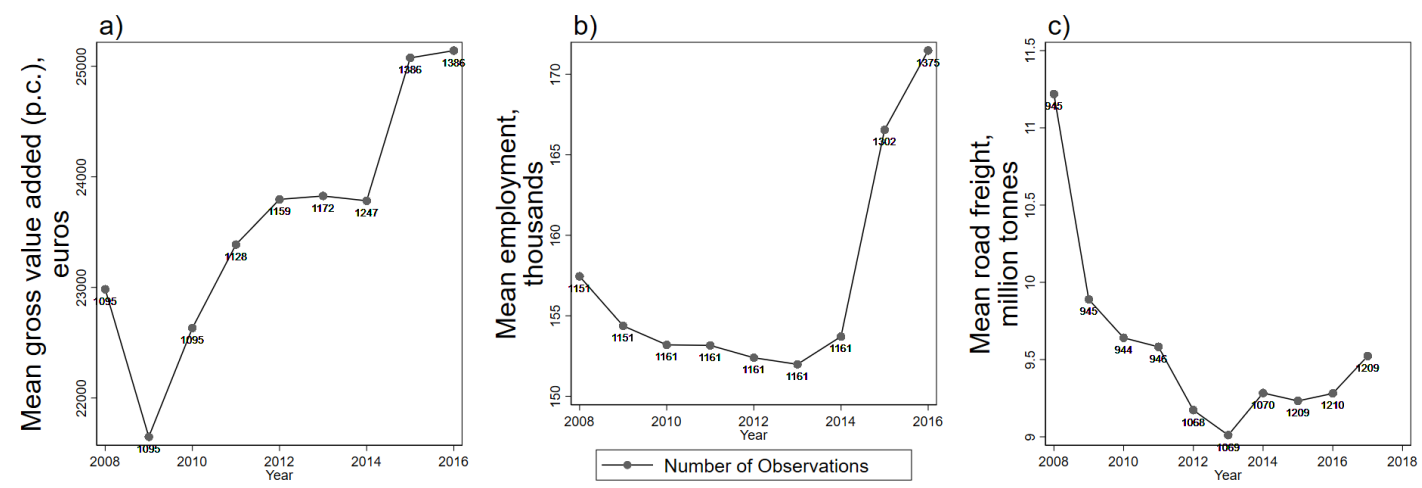

Figure 1 shows the mean values of the three dependent variables over the whole sample period. Figure 1a) reveals the sharp decrease in mean per capita gross value added in Europe after 2008. However, it has been increasing ever since, peaking at 25.14 thousand euros in 2016 (21.65 thousand euros in 2009). A similar but less severe decrease can be observed for mean employment depicted in Figure 1b). Admittedly, the rebound is not as immediate as for mean per capita gross value added. After not experiencing too much change for five years, mean employment grew sharply again in the years 2015 and 2016. Lastly, Figure 1c) illustrating mean road freight arguably exhibits the sharpest drop after 2008. Moreover, other than the first two variables, it does not seem to have for the purpose of: The collection, development and harmonization of European regional statistics, [s]ocio-economic analyses of the regions [..., and] [f]raming of EU regional policies" (Eurostat 2019)

${ }^{5}$ The spatial dimensions of treatment has been depicted in Table A1 (see Appendix). 
fully recovered, despite a turnaround in 2013 . In 2017 , the mean road freight $(\approx 9.52$ million tonnes) was still well below its 2008 value $(\approx 11.22$ million tonnes).

\section{Results}

In this section, we will present and analyze the empirical results. We will first investigate the findings of the baseline model for all three dependent variables of interest. We will then elaborate on the findings in pursuit of our identification strategy employing matching econometrics. In addition to this, we will check for spillover effects by including the bordering NUTS-3 areas. Also, we will discuss some initial findings for specific sectors and to what extent these divert from aggregate results. Eventually, we also check the robustness of the result using a randomized samples of treated and control groups.

\subsection{Baseline model findings}

The baseline FE specification yields a negative but insignificant relationship between railway connections and per capita gross value added (see column (1) of Table 2). As discussed in the section on theoretical considerations, the short-run impact associated with the establishment of a new transport hub may be small on the aggregate level. Existing firms may be less dependent on China and the sorting of new firms may take some time.

The railway connection coefficient estimated using regional employment as dependent variable is positive and significant at the ten percent level. This result contradicts the first result. Additional input of labor into the production should lead to a higher output. However, the results presented in Table (2) are based on aggregate numbers containing potential employees working in manufacturing and potential employees working in service. The results may be driven by additional employment in the transport sector. We will investigate this hypothesis using sectoral data in the matching econometrics 
Table 2: CR express' impact on local development

\begin{tabular}{|c|c|c|c|}
\hline Dep. Var.: & $\begin{array}{l}\text { p.c. gross value } \\
\text { added }\end{array}$ & employment & road freight \\
\hline & (1) & $(2)$ & $(3)$ \\
\hline Rail connection & $\begin{array}{l}-0.0393 \\
(0.0252)\end{array}$ & $\begin{array}{c}0.021^{*} \\
(0.0119)\end{array}$ & $\begin{array}{c}0.0431 \\
(0.0712)\end{array}$ \\
\hline Population density & $\begin{array}{l}1.64 \mathrm{e}-05^{* *} \\
(8.03 \mathrm{e}-06)\end{array}$ & $\begin{array}{c}9.45 \mathrm{e}-06 \\
(6.70 \mathrm{e}-06)\end{array}$ & $\begin{array}{l}-3.97 \mathrm{e}-05 \\
(3.15 \mathrm{e}-05)\end{array}$ \\
\hline GDP per capita & & $\begin{array}{c}6.01 \mathrm{e}-06^{* * *} \\
(1.41 \mathrm{e}-06)\end{array}$ & $\begin{array}{c}2.36 \mathrm{e}-05^{* * *} \\
(3.91 \mathrm{e}-06)\end{array}$ \\
\hline Constant & $\begin{array}{c}9.845^{* * *} \\
(0.00519)\end{array}$ & $\begin{array}{l}4.506^{* * *} \\
(0.0368)\end{array}$ & $\begin{array}{c}1.354^{* * *} \\
(0.101)\end{array}$ \\
\hline Observations & 10,625 & 10,500 & 8,979 \\
\hline R-squared & 0.408 & 0.174 & 0.069 \\
\hline Number of id & 1,376 & 1,375 & 1,184 \\
\hline Fixed effects & YES & YES & YES \\
\hline Year Dummies & YES & YES & YES \\
\hline Observations & 10,625 & 10,500 & 8,979 \\
\hline R-squared & 0.006 & 0.126 & 0.008 \\
\hline Counties & 1,376 & 1,375 & 1,184 \\
\hline
\end{tabular}

Standard errors in parentheses; ${ }^{* * *} \mathrm{p}<0.01, * * \mathrm{p}<0.05,{ }^{*} \mathrm{p}<0.1$. The dependent variables in specifications (1) to (3) are log-linearized. (1) fits the model to per capita gross value added, (2) fits the model to the level of regional employment and (3) fits the model to the amount of road freight. The variable of interest is the rail connection dummy. Coefficients for the control variables coast, port, urban and metro are estimated but not reported

application.

The coefficient for the road freight regression is statistically insignificant.

Nonetheless, the baseline model specification suffers from several problems of the data that need to be addressed: Firstly, the assignment of China-Europe rail connections is not random. Secondly, there is the differential impact of treatment in the treated and 
untreated sample.

These issues can be approached through matching econometrics. The matching itself forms treated and control groups consisting of NUTS-3 regions that are as similar as possible. The algorithm searches for statistical twins across the treatment and the control group. Differences in the outcome variables between the treatment and the control group must stem from the treatment if the matching itself is successful.

\subsection{Matching results}

Following the logic depicted in section 3.3, we utilize two different matching approaches, Mahalanobis Distance Matching (MDM) and Coarsened Exact Matching (CEM).

Table 3: The growth effect of CR express

\begin{tabular}{lcccc}
\hline & \multicolumn{4}{c}{ Dep Var: Per capita gross value added (logs) } \\
\cline { 2 - 5 } & $(1)$ & $(2)$ & $(3)$ & $(4)$ \\
\hline Rail connection & $\begin{array}{c}-0.0673 \\
(0.0946)\end{array}$ & $\begin{array}{c}-0.0673 \\
(0.0946)\end{array}$ & \\
Rail connection \\
(larger area)
\end{tabular}

Proceeding as such for the growth effect of the railway connections, we achieve identical treatment estimates for MDM and CEM (see columns (1)-(2) of Table 3), both negative and insignificant. Also, the slight reduction of the sample through the coarsening algorithm in column (2) does not effect the balancing conditions. Theoretically these findings appears reasonable as the treatment period is rather short and changes in gross value added are expected to emerge at a substantial lag. However, enlarging the 
examined treatment group to the areas surrounding the immediate destinations produces negative estimates ${ }^{6}$.

Table 4: The development effect of CR express

\begin{tabular}{|c|c|c|c|c|}
\hline & \multicolumn{4}{|c|}{ Dep Var: Employment (logs) } \\
\hline & $(1)$ & $(2)$ & $(3)$ & $(4)$ \\
\hline Rail connection & $\begin{array}{c}0.503^{* * *} \\
(0.167)\end{array}$ & $\begin{array}{c}0.519^{* * *} \\
(0.177)\end{array}$ & & \\
\hline $\begin{array}{l}\text { Rail connection } \\
\text { (larger area) }\end{array}$ & & & $\begin{array}{l}0.256^{* * *} \\
(0.0695)\end{array}$ & $\begin{array}{l}0.254^{* * *} \\
(0.0706)\end{array}$ \\
\hline Observations & 10,500 & 8,675 & 10,500 & 10,132 \\
\hline \multicolumn{5}{|c|}{$\begin{array}{l}\text { Standard errors in parentheses; }{ }^{* * *} \mathrm{p}<0.01,{ }^{* *} \mathrm{p}<0.05, * \mathrm{p}<0.1 . \quad(1) \\
\text { and (3): Mahalanobis distance matching }(\mathrm{MDM}) ;(2) \text { and }(4) \text { : Ma- } \\
\text { halanobis distance matching }(\mathrm{MDM}) \text { with coarsened exact matches } \\
(\mathrm{CEM})\end{array}$} \\
\hline
\end{tabular}

For the development effect of the railway connections, a significantly positive relationship between the treatment and employment can be confirmed. Theoretically, this revelation is in line with the higher elasticity of labor markets as compared to overall economic growth. The results from MDM and CEM estimates are again comparable. Having said this, investigating the balancing conditions of both specifications reveals that the control group constructed through CEM is much closer to the original treatment group, a finding that also holds for the results in the larger area, which are reported in columns (3) and (4) of Table 4. Generally speaking, the estimates depicted in columns (2) and (4) identify a positive treatment effect on local employment, which is significant at the $1 \%$ level. At a later stage, we will also shed some light on data disaggregated by

\footnotetext{
${ }^{6}$ Note that while the treatment coefficients in Table 3 are negative in terms of per capita gross value added, they are positive in terms of aggregate gross value added. Because rail connection might also impact population, which is endogenous to economic output, the significant negative effects on per capita gross value added for the enlarged treatment group need to be interpreted with caution. We announce this as a caveat to our results.
} 
sector to identify which parts of the economy might be especially exposed to the effects of treatment.

Table 5: The connectivity effect of CR express

\begin{tabular}{lcccc}
\hline \multicolumn{5}{c}{ Dep Var: Road freight (logs) } \\
\cline { 2 - 5 } & $(1)$ & $(2)$ & $(3)$ & $(4)$ \\
\hline Rail connection & $\begin{array}{c}0.232^{* *} \\
(0.115)\end{array}$ & $\begin{array}{c}0.225^{* *} \\
(0.114)\end{array}$ & & \\
$\begin{array}{l}\text { Rail connection } \\
\text { (larger area) }\end{array}$ & & & $0.323^{* * *}$ & $0.294^{* * *}$ \\
\hline Observations & 8,979 & 7,295 & $8,0766)$ & $(0.0768)$ \\
\hline
\end{tabular}

Standard errors in parentheses; ${ }^{* * *} \mathrm{p}<0.01,{ }^{* *} \mathrm{p}<0.05,{ }^{*} \mathrm{p}<0.1$. (1) and (3): Mahalanobis distance matching (MDM); (2) and (4): Mahalanobis distance matching $(\mathrm{MDM})$ with coarsened exact matches (CEM)

Lastly, the matching results for the connectivity effect of the railway connections (see Table 5) appear to be significant and positive for both the core regions, as well as the larger area. This finding delivers substantial evidence for the notion of intermodal transport depicted in section 2. That is to say that rather than shifting freight away from the road in favor of railroads, both modes of transport serve as complements.

\subsection{Sectoral Analysis}

To extend the scope of our analysis, we deployed the matching techniques utilized above to sectoral gross value added and employment data. Comparing the MDM results depicted in Tables 6 and 7 to the aggregate results in the first columns of Table 3 and 4 carries some valuable additional insights.

The only significant treatment estimate in column (5) of Table 6 associates treatment with a reduction in per capita gross value added in the public sector. Although 
Table 6: The growth effect of CR express, sectoral analysis

\begin{tabular}{|c|c|c|c|c|c|}
\hline & \multicolumn{5}{|c|}{ Dep Var: Per capita value added (logs) } \\
\hline & $\begin{array}{l}(1) \\
\text { B-E }\end{array}$ & $\begin{array}{c}(2) \\
\mathrm{C}\end{array}$ & $\begin{array}{c}(3) \\
\text { G-J }\end{array}$ & $\begin{array}{c}(4) \\
\mathrm{K}-\mathrm{N}\end{array}$ & $\begin{array}{c}(5) \\
\text { O-U }\end{array}$ \\
\hline Rail connection & $\begin{array}{c}-0.0307 \\
(0.123)\end{array}$ & $\begin{array}{c}-0.0384 \\
(0.155)\end{array}$ & $\begin{array}{c}0.162 \\
(0.108)\end{array}$ & $\begin{array}{c}0.00184 \\
(0.114)\end{array}$ & $\begin{array}{c}-0.193^{*} \\
(0.104)\end{array}$ \\
\hline Observations & 10,253 & 10,410 & 10,417 & 10,417 & 10,417 \\
\hline \multicolumn{6}{|c|}{$\begin{array}{l}\text { Standard errors in parentheses; }{ }^{* * *} \mathrm{p}<0.01,{ }^{* *} \mathrm{p}<0.05,{ }^{*} \mathrm{p}<0.1 . \quad(1) \text { to } \\
(5) \text { : Mahalanobis distance matching }(\mathrm{MDM}) \text { with coarsened exact matches } \\
(\mathrm{CEM} \text { ). Sectors according to Eurostat: B-E: Mining and quarrying; manu- } \\
\text { facturing; electricity, gas, steam and air conditioning supply; water supply; } \\
\text { sewerage, waste management and remediation activities; C: Manufacturing; } \\
\text { G-J: Wholesale and retail trade; repair of motor vehicles and; motorcycles } \\
\text { transportation and storage; accommodation and food service activities; in- } \\
\text { formation and communication; K-N: Financial and insurance activities; real } \\
\text { estate activities; professional, scientific and technical activities; administra- } \\
\text { tive activities; professional, scientific and technical activities; administrative } \\
\text { and support service activities; O-U: Public administration and defence; com- } \\
\text { pulsory social security; education; human health and social work activities; } \\
\text { arts, entertainment and recreation; other service activities; activities of house- } \\
\text { holds as employers; undifferentiated goods- and services-producing activities of } \\
\text { households for own use; activities of extraterritorial organisations and bodies. }\end{array}$} \\
\hline
\end{tabular}

estimates for all other depicted sectors turn out insignificant at the $10 \%$ level, this extension actually reveals that signs and the effective direction of treatment might differ for any given sector. For instance, the sector encompassing wholesale and retail trade, which, arguably, is heavily involved in CR express activities, shows a positive treatment coefficient.

With respect to employment, just as aggregate results depicted in columns (2) of Table 4, all sectors yield positive and significant treatment effects. In terms of magnitude, the effect is largest for employment in the manufacturing sector (see column (2) of Table 7), exceeding the coefficient for aggregate employment. Once again, this confirms that gains from CR express might be distributed unevenly among different sectors of the local 
Table 7: The development effect of CR express, sectoral analysis

\begin{tabular}{|c|c|c|c|c|c|}
\hline & \multicolumn{5}{|c|}{ Dep Var: Per capita value added (logs) } \\
\hline & $\begin{array}{l}(1) \\
\text { B-E }\end{array}$ & $\begin{array}{c}(2) \\
\mathrm{C}\end{array}$ & $\begin{array}{l}(3) \\
\text { G-J }\end{array}$ & $\begin{array}{c}(4) \\
\mathrm{K}-\mathrm{N}\end{array}$ & $\begin{array}{c}(5) \\
\text { O-U }\end{array}$ \\
\hline Rail connection & $\begin{array}{c}0.563^{* * *} \\
(0.137)\end{array}$ & $\begin{array}{c}0.678^{* * *} \\
(0.162)\end{array}$ & $\begin{array}{c}0.515^{* * *} \\
(0.191)\end{array}$ & $\begin{array}{c}0.508^{* * *} \\
(0.187)\end{array}$ & $\begin{array}{c}0.423^{* * *} \\
(0.158)\end{array}$ \\
\hline Observations & 10,338 & 10,490 & 10,473 & 10,470 & 10,500 \\
\hline \multicolumn{6}{|c|}{$\begin{array}{l}\text { Standard errors in parentheses; }{ }^{* *} \mathrm{p}<0.01,{ }^{*} \mathrm{p}<0.05,{ }^{*} \mathrm{p}<0.1 . \quad(1) \text { to (5): Ma- } \\
\text { halanobis distance matching (MDM) with coarsened exact matches (CEM). Sectors } \\
\text { according to Eurostat: B-E: Mining and quarrying; manufacturing; electricity, gas, } \\
\text { steam and air conditioning supply; water supply; sewerage, waste management and } \\
\text { remediation activities; C: Manufacturing; G-J: Wholesale and retail trade; repair } \\
\text { of motor vehicles and; motorcycles transportation and storage; accommodation and } \\
\text { food service activities; information and communication; K-N: Financial and insurance } \\
\text { activities; real estate activities; professional, scientific and technical activities; admin- } \\
\text { istrative activities; professional, scientific and technical activities; administrative and } \\
\text { support service activities; O-U: Public administration and defence; compulsory social } \\
\text { security; education; human health and social work activities; arts, entertainment and } \\
\text { recreation; other service activities; activities of households as employers; undifferen- } \\
\text { tiated goods- and services-producing activities of households for own use; activities } \\
\text { of extraterritorial organisations and bodies. }\end{array}$} \\
\hline
\end{tabular}

economy. The fact that manufacturing is the sector most strongly enjoying those gains with regard to employment can also be associated with its relative importance in $\mathrm{CR}$ express related trade.

The most important contribution of expanding analysis to data on the sector level is to highlight the differential impact of CR express. Although aggregate results might hint in one direction, results are slightly more diverse for employment and might even be running in contrary direction for per capita gross value added. 


\subsection{Robustness Checks}

To underline the validity of our findings, we also ran a placebo test. To do so, we constructed randomized treatment groups, equally large as the larger area treatment sample for the year 2015 and ran several iterations with road freight as the dependent variable using the previously applied CEM specification.

Table 8: The connectivity effect of CR express, robustness check

\begin{tabular}{|c|c|c|c|c|c|c|}
\hline & \multicolumn{6}{|c|}{ Dep. Var.: Road freight $(\operatorname{logs}), 2015$} \\
\hline & $(1)$ & $(2)$ & $(3)$ & $(4)$ & $(5)$ & $(6)$ \\
\hline & Real Treatment & $\begin{array}{c}\text { Robustness Check } \\
\text { Iteration } 1\end{array}$ & $\begin{array}{l}\text { Robustness Check } \\
\text { Iteration } 2\end{array}$ & $\begin{array}{c}\text { Robustness Check } \\
\text { Iteration } 3\end{array}$ & $\begin{array}{c}\text { Robustness Check } \\
\text { Iteration } 4\end{array}$ & $\begin{array}{c}\text { Robustness Check } \\
\text { Iteration } 5\end{array}$ \\
\hline $\begin{array}{l}\text { Rail connection } \\
\text { (larger area) }\end{array}$ & $\begin{array}{c}0.520^{* * *} \\
(0.201)\end{array}$ & & & & & \\
\hline $\begin{array}{l}\text { Randomized } \\
\text { treatment }\end{array}$ & & $\begin{array}{c}0.182 \\
(0.163)\end{array}$ & $\begin{array}{r}-0.0703 \\
(0.180)\end{array}$ & $\begin{array}{l}-0.161 \\
(0.208)\end{array}$ & $\begin{array}{r}-0.0405 \\
(0.189)\end{array}$ & $\begin{array}{c}0.000887 \\
(0.160)\end{array}$ \\
\hline Observations & 1,130 & 1,080 & 1,129 & 1,097 & 1,078 & 1,120 \\
\hline
\end{tabular}

While the positive and significant estimate in column (1) of Table 8 for the real treatment group is consistent with the aggregate results depicted in column (4) of Table 5 , the randomized control groups show no comparable relationship to road freight volume. Also, the coefficient's increment as compared to the pooled regression illustrates the additional fact, that the magnitude of treatment is fluctuating over time.

\section{Conclusion}

One of the focus of the Belt and Road Initiative is connecting East Asia and Europe through new transportation corridors. For the land route of the New Silk Road, the connection is mainly realized by transcontinental railways, especially through the ChinaEurope Express, which connect an increasing number of Chinese cities with cities in Europe and Asia. By using matching as the identification strategy, we rigorously illustrate the relationship between the CR Express and local economic development. The 
depicted results manage to supply substantial evidence to support the positive effects of railway connections on local employment and road freight transportation, although there is little effect on total regional economic output so far. The magnitude of the treatment effects is subject to the chosen model specification. In addition, the findings show that the treatment effects of the CR Express spill over into its surrounding regions, and that sectoral differences play an important role. In sum, we can carefully conclude that increased connectivity brought by the CR Express has already generated real impacts on local economic activities in its terminal cities and areas around, even though there is little direct investment in new infrastructure building concerning the CR express at the moment. This, together with the fact that more investment in infrastructure building is in pipeline and more rail connections will be established as China continues to push for the BRI into the future, deserves future attention.

\section{References}

Abadie, Alberto, David Drukker, et al. (2004). "Implementing matching estimators for average treatment effects in Stata”. In: Stata journal 4, pp. 290-311. ISSN: 1536-867X.

Abadie, Alberto and Guido W. Imbens (2006). "Large sample properties of matching estimators for average treatment effects". In: Econometrica 74.1, pp. 235-267. ISSN: 0012-9682.

- (2011). "Bias-corrected matching estimators for average treatment effects". In: Journal of Business \& Economic Statistics 29.1, pp. 1-11. ISSN: 0735-0015.

Belt and Road Portal (2019). CR express in 2018: 6300 rounds and a year on year rise of 72\%. URL: https://www.yidaiyilu.gov.cn/xwzx/gnxw/76434.htm (visited on 04/18/2019). 
Besharati, Babak et al. (2017). "The ways to maintain sustainable China-Europe block train operation". In: Business and Management Studies 3.3, pp. 25-33. ISSN: 23745924.

Bruinsma, Frank, Peter Nijkamp, and Piet Rietveld (1990). "Employment impacts of infrastructure investments". In: Infrastructure and the Space-Economy. Ed. by Infrastructure and the Space-Economy: Essays in Honor of Rolf Funck. Springer, pp. 209226.

Button, Kenneth (1998). "Infrastructure investment, endogenous growth and economic convergence". In: The Annals of Regional Science 32.1, pp. 145-162. ISSN: 0570-1864.

Chen, Maggie Xiaoyang and Chuanhao Lin (2018). "Foreign Investment across the Belt and Road : Patterns, Determinants, and Effects". In: World Bank Policy Research Working Paper.WPS8607. URL: http://documents . worldbank.org/curated/en/ 394671539175518256/pdf/WPS8607.pdf (visited on 08/15/2019).

Chen, Xi et al. (2017). "Game-Theoretic Comparison Approach for Intercontinental Container Transportation: A Case between China and Europe with the B\&R Initiative". In: Journal of Advanced Transportation 2017. ISSN: 0197-6729.

Cochran, William G. and Donald B. Rubin (1973). "Controlling Bias in Observational Studies: A Review". In: Sankhyā: The Indian Journal of Statistics, Series A (19612002) 35.4, pp. 417-446. ISSN: 0581572X. URL: http://www.jstor .org/stable/ 25049893 (visited on 08/15/2019).

Council, Hong Kong Trade Development (2018). Connecting the CR Express with "Belt and Road"Logistics Networks. URL: https : / / hkmb.hktdc.com/en/1XOAE3FC/ hktdc - research / Connecting - the - CR - Express - with - \%E2\%80\%9CBelt - and Road\%E2\%80\%9D-Logistics-Networks (visited on 08/15/2019).

Dalenberg, Douglas R., Mark D. Partridge, and Dan S. Rickman (1998). "Public infrastructure: pork or jobs creator?" In: Public Finance Review 26.1, pp. 24-52. ISSN: 1091-1421. 
Du, Qiwen and Xianliang Shi (2017). "A Study on the Government Subsidies for CR Express Based on Dynamic Games of Incomplete Information". In: Periodica Polytechnica Transportation Engineering 45.3, pp. 162-167. ISSN: 1587-3811.

Eberts, Randall W and Joe Allan Stone (1992). Wage and employment adjustment in local labor markets. WE Upjohn Institute for Employment Research.

European Parliament, Council of the European Union (May 26, 2003). Regulation (EC) No $1059 / 20031$.

Eurostat (2016). International trade in goods by mode of transport. URL: https://ec . europa.eu/eurostat/statistics-explained/index .php?title=International_ trade_in_goods_by_mode_of_transport (visited on 08/15/2019).

- (2017). Globalization patterns in EU trade and investment. URL: https : / / ec . europa . eu / eurostat/web/products - statistical-books/- /KS - 06-17-380 (visited on 08/15/2019).

- (2018). Freight transport in the EU-28: Model split of inland transport modes (\% of total tonne-killometres). URL: https : / / ec . europa . eu/eurostat/statistics explained/index.php/Freight_transport_statistics___modal_split (visited on $08 / 15 / 2019)$.

- (2019). Extra EU trade since 2000 by mode of transport (HS2-HS4). URL: https:// ec. europa.eu/eurostat/web/international-trade-in-goods/data/database (visited on $08 / 15 / 2019$ ).

Fudan Institute of Belt and Road \& Global Governance (Mar. 13, 2019). CR express data analysis for the year 2018. URL: http://brgg.fudan.edu.cn/articleinfo_ 700_3.html (visited on 08/15/2019).

Gleave, Steer Davies (2018). "Research for TRAN Committee: The new Silk Routeopportunities and challenges for EU transport". In: European Parliament, Policy Department for Structural and Cohesion Policies, Brussels. 
Global Times (May 13, 2019). Subsidies for China-Europe Freight Trains raise concern. URL: http://ies.cass.cn/english/chinare/cere/201701/t20170106_3373995. shtml (visited on 08/15/2019).

Guo, Shenyang and Mark W. Fraser (2015). Propensity score analysis: Statistical methods and applications. 2nd edition. Vol. 11. Advanced quantitative techniques in the social sciences series. Los Angeles et al.: SAGE. ISBN: 9781452235004.

Haughwout, Andrew F. (1999). "State infrastructure and the geography of employment". In: Growth and Change 30.4, pp. 549-566. ISSN: 0017-4815.

Herrero, Alicia Garcia and Jianwei Xu (2017). "China's Belt and Road Initiative: Can Europe Expect Trade Gains?" In: China 8 World Economy 25.6, pp. 84-99. ISSN: $1671-2234$.

Holland, Tom (Apr. 24, 2017). "Puffing across the 'One Belt, One Road' rail route to nowhere". In: South China Morning Post. URL: https : //www . scmp . com/weekasia/business/article/2089507/puffing-across-one-belt-one-road-railroute-nowhere (visited on 08/16/2019).

Iacus, Stefano M., Gary King, and Giuseppe Porro (2012). "Causal Inference without Balance Checking: Coarsened Exact Matching". In: Political Analysis 20.1, pp. 1-24. ISSN: 1047-1987. DOI: 10.1093/pan/mpr013.

Iacus, Stefano Maria, Gary King, and Giuseppe Porro (2008). "Matching for Causal Inference Without Balance Checking". In: SSRN Electronic Journal. DOI: 10.2139/ ssrn. 1152391.

Ito, A. (2019). "China's Belt and Road Initiative and Japan's Response: from Nonparticipation to Conditional Engagement". In: East Asia. ISSN: 10966838. DOI: 10 . $1007 / \mathrm{s} 12140-019-09311-z$.

Li, Han and Zhigang Li (2013). "Road investments and inventory reduction: Firm level evidence from China". In: Journal of Urban Economics 76, pp. 43-52. ISSN: 00941190. DOI: $10.1016 / j \cdot j u e .2013 .02 .002$. 
Li, Yuan, Kierstin Bolton, and Theo Westphal (2018). "The effect of the New Silk Road railways on aggregate trade volumes between China and Europe". In: Journal of Chinese Economic and Business Studies, pp. 1-18. ISSN: 1476-5284.

Ma, Bin (2018). "The development, issues and solutions of China-EU express". In: China International Studies 6.

National Development and Reform Commission of People's Republic of China (2016). CR Express development plan for 2016-2020.

Rietveld, Piet (1989). "Infrastructure and regional development". In: The Annals of Regional Science 23.4, pp. 255-274. ISSN: 0570-1864.

Rietveld, Piet and Frank Bruinsma (2012). Is transport infrastructure effective?: transport infrastructure and accessibility: impacts on the space economy. Springer Science \& Business Media. ISBN: 3642722326 .

Rodrigue, J., C. Comtois, and B. Slack (2016). "Transportation modes, modal competition and modal shift". In: The Geography of Transport Systems.(come from: https://transportgeography. org/).

Rodrigue, Jean-Paul, Claude Comtois, and Brian Slack (2009). The geography of transport systems. Routledge. ISBN: 1134015097.

Shepard, Wade (Mar. 22, 2018). "The Hidden Economic Rationale of China-Europe Rail". In: Forbes. URL: https ://www . forbes . com/sites/wadeshepard/2018/03/ 22/the-hidden-economic-rationale-of-china-europe-rail/\#3b6ba15e40d1 (visited on $08 / 15 / 2019$ ).

Soyres, François de et al. (2018). "How Much Will the Belt and Road Initiative Reduce Trade Costs?" In: The World Bank Policy Research Working Paper WPS8614. URL: http : / / documents . worldbank . org / curated / en / 592771539630482582 / pdf / WPS8614.pdf (visited on 08/15/2019). 
Thurer, M. et al. (2018). "A systematic review of China's belt and road initiative: implications for global supply chain management". In: International Journal of Production Research. ISSN: 00207543. DOI: 10.1080/00207543.2019.1605225.

Vickerman, Roger (2008). "Recent Evolution of Research into the Wider Economic Benefit of Transport Infrastructure Investments". In: International Transport Forum, The Wider Economic Benefits of Transport:Macro-, Meso- and Micro-Economic Transport Planning and Investment Tools. Paris: OECD Publishing.

Vinokurov, Evgeny and Taras Tsukarev (2018). "The Belt and Road Initiative and the transit countries: an economic assessment of land transport corridors". In: Area Development and Policy 3.1, pp. 93-113. ISSN: 2379-2949.

Yoshino, Naoyuki, Matthias Helble, Umid Abidhadjaev, et al. (2018). Financing Infrastructure in Asia and the Pacific: Capturing Impacts and New Sources. Asian Development Bank Institute. 


\section{Appendix}

Table A1: CR express destinations and associated larger areas

\begin{tabular}{|l|l|}
\hline Destination & Larger area \\
\hline Hamburg & Harburg \\
& Stade \\
& Pinneberg \\
& Segeberg \\
& Stormarn \\
Perzogtum Lauenburg & Central Bohemian Region \\
& Hradec Kralove Region \\
& Vysocina Region \\
& South Moravian Region \\
& Olomouc Region \\
& Walbrzych County \\
& Mettmann \\
& Rhein-Kreis Neuss \\
& Wesel \\
& Duesseldorf \\
& Krefeld \\
& Muelheim an der Ruhr \\
& Oberhausen \\
& Province of Toledo \\
& Province of Guadalajara \\
& Province of Segovia \\
& Province of Cuenca \\
Madrid & Province of Avila \\
& Greater Warsaw East \\
& Greater Warsaw West \\
& Chelmsko-zamojski \\
Malaszewicze & Lubelski \\
& Pulawski \\
& Siedlecki \\
& Lomzynski \\
Greater Lodz \\
\end{tabular}




\section{Balancing Conditions}

Table A2: Balancing conditions for Table 3

\begin{tabular}{ll|l|l|l|l}
\multirow{2}{*}{} & \multicolumn{2}{|l|}{ Standardized differences } & \multicolumn{2}{l}{ Variance ratio } \\
\cline { 2 - 5 } & Raw & Matched & Raw & Matched \\
\hline \multirow{3}{*}{ (1) } & -0.5080395 & 0 & 0.5657118 & 1 \\
port & 0.0434658 & 0 & 1.065332 & 1 \\
urban & 0.1251063 & 0 & 0.9451161 & 1 \\
metro & 0.6473161 & 0 & 0.9061346 & 1 \\
density & 0.7853993 & 0.0104141 & 0.727655 & 1.009193 \\
\hline \multirow{2}{*}{ (2) } & coast & -0.4866815 & 0 & 0.5725779 & 1 \\
port & 0.0462573 & 0 & 1.067239 & 1 \\
urban & 0.1401514 & 0 & 0.9367485 & 1 \\
metro & 0.6719595 & 0 & 0.9153832 & 1 \\
& density & 1.178843 & 0.0104141 & 2.46453 & 1.009193 \\
\hline & coast & -0.8426598 & 0 & 0.2129894 & 1 \\
port & 0.0301901 & 0 & 1.02486 & 1 \\
(3) & urban & 0.2257965 & 0 & 0.8294543 & 1 \\
metro & 0.5474189 & 0 & 0.9533514 & 1 \\
density & 0.1795834 & 0.0029578 & 0.5014671 & 1.006186 \\
\hline & coast & -0.8201751 & 0 & 0.2154977 & 1 \\
port & 0.0330456 & 0 & 1.026724 & 1 \\
(4) & urban & 0.2412938 & 0 & 0.8220788 & 1 \\
metro & 0.5719974 & 0 & 0.9635729 & 1 \\
density & 0.4281946 & 0.0029578 & 1.718602 & 1.006186
\end{tabular}

Table A3: Balancing conditions for Table 4

\begin{tabular}{|c|c|c|c|c|c|}
\hline & \multicolumn{2}{|c|}{ Standardized differences } & \multicolumn{2}{|c|}{ Variance ratio } \\
\hline & & Raw & Matched & Raw & Matched \\
\hline \multirow{6}{*}{ (1) } & coast & -0.3966244 & 0 & 0.6972304 & 1 \\
\hline & port & 0.2530197 & 0 & 1.149627 & 1 \\
\hline & urban & 0.145972 & 0 & 0.9364439 & 1 \\
\hline & metro & 0.6713611 & 0 & 0.8968426 & 1 \\
\hline & density & 0.7291745 & 0.0370245 & 0.612893 & 1.053926 \\
\hline & gdp_capita & 0.2393715 & 0.0277692 & 0.8120435 & 1.126007 \\
\hline \multirow{6}{*}{ (2) } & coast & -0.3765156 & 0 & 0.7051762 & 1 \\
\hline & port & 0.2748019 & 0 & 1.165917 & 1 \\
\hline & urban & 0.2091099 & 0 & 0.9048924 & 1 \\
\hline & metro & 0.7517194 & 0 & 0.9301403 & 1 \\
\hline & density & 1.213298 & 0.0340035 & 2.324461 & 1.050849 \\
\hline & gdp_capita & 0.6568173 & 0.0111534 & 3.575619 & 1.087231 \\
\hline \multirow{6}{*}{ (3) } & coast & -0.815676 & 0 & 0.2425751 & 1 \\
\hline & port & 0.1389103 & 0 & 1.076683 & 1 \\
\hline & urban & 0.2755791 & 0 & 0.7815072 & 1 \\
\hline & metro & 0.5659553 & 0 & 0.9429105 & 1 \\
\hline & density & 0.1934936 & 0.01648 & 0.4737544 & 1.026497 \\
\hline & gdp_capita & 0.0182805 & 0.0120408 & 0.6055347 & 1.028898 \\
\hline \multirow{6}{*}{ (4) } & coast & -0.7911175 & 0 & 0.2456765 & 1 \\
\hline & port & 0.1395536 & 0 & 1.077113 & 1 \\
\hline & urban & 0.3032304 & 0 & 0.769407 & 1 \\
\hline & metro & 0.6108333 & 0 & 0.9620719 & 1 \\
\hline & density & 0.5038322 & 0.0146624 & 1.927292 & 1.026863 \\
\hline & gdp_capita & 0.1344489 & 0.0107029 & 1.538154 & 1.015709 \\
\hline
\end{tabular}


Table A4: Balancing conditions for Table 5

\begin{tabular}{l|l|l|l|l}
\multirow{2}{*}{} & \multicolumn{2}{|l|}{ Standardized differences } & Variance ratio \\
\cline { 2 - 5 } & Raw & Matched & Raw & Matched \\
\hline \multirow{2}{*}{ coast } & -0.21858 & 0 & 0.8408543 & 1 \\
port & 0.4443195 & 0 & 1.170329 & 1 \\
urban & 0.1460085 & 0 & 0.9384068 & 1 \\
metro & 0.6720445 & 0 & 0.8832247 & 1 \\
density & 0.8251561 & 0.0663761 & 0.7455403 & 1.053926 \\
gdp_capita & 0.3643082 & 0.0793705 & 0.9892297 & 1.234981 \\
\hline coast & -0.1985487 & 0 & 0.8543849 & 1 \\
port & 0.4790453 & 0 & 1.199295 & 1 \\
urban & 0.2057246 & 0 & 0.9061769 & 1 \\
metro & 0.7355217 & 0 & 0.9065762 & 1 \\
density & 1.198427 & 0.0677156 & 2.033831 & 1.127224 \\
gdp_capita & 0.8046631 & 0.0722988 & 3.435459 & 1.236125 \\
\hline coast & -0.692364 & 0 & 0.2780206 & 1 \\
port & 0.2385762 & 0 & 1.119568 & 1 \\
urban & 0.2913933 & 0 & 0.7568923 & 1 \\
metro & 0.5612237 & 0 & 0.9300815 & 1 \\
density & 0.2854149 & 0.0188022 & 0.6570756 & 1.035189 \\
gdp_capita & 0.0738939 & 0.0202715 & 0.7303747 & 1.049448 \\
\hline coast & -0.6810522 & 0 & 0.2803397 & 1 \\
port & 0.2414188 & 0 & 1.121769 & 1 \\
urban & 0.3130409 & 0 & 0.7470201 & 1 \\
metro & 0.5940509 & 0 & 0.9426556 & 1 \\
density & 0.5179347 & 0.0163446 & 1.932943 & 1.036825 \\
gdp_capita & 0.1742136 & 0.0204643 & 1.416312 & 1.041654
\end{tabular}

Table A5: Balancing conditions for Table 6

\begin{tabular}{|c|c|c|c|c|c|}
\hline & \multicolumn{2}{|c|}{ Standardized differences } & \multicolumn{2}{|c|}{ Variance ratio } \\
\hline & & Raw & Matched & Raw & Matched \\
\hline \multirow{5}{*}{ (1) } & coast & -0.4851468 & 0 & 0.5730954 & 1 \\
\hline & port & 0.0424614 & 0 & 1.064647 & 1 \\
\hline & urban & 0.1464276 & 0 & 0.9334181 & 1 \\
\hline & metro & 0.6816717 & 0 & 0.9192992 & 1 \\
\hline & density & 1.223572 & 0.0029369 & 2.801044 & 0.9853345 \\
\hline \multirow{5}{*}{$(2)$} & coast & -0.4862786 & 0 & 0.5727137 & 1 \\
\hline & port & 0.0466492 & 0 & 1.067508 & 1 \\
\hline & urban & 0.1401689 & 0 & 0.936739 & 1 \\
\hline & metro & 0.6717074 & 0 & 0.9152836 & 1 \\
\hline & density & 1.178706 & 0.0104141 & 2.463966 & 1.009193 \\
\hline \multirow{5}{*}{$(3)$} & coast & -0.4872183 & 0 & 0.5723974 & 1 \\
\hline & port & 0.0457353 & 0 & 1.06688 & 1 \\
\hline & urban & 0.1406595 & 0 & 0.9364755 & 1 \\
\hline & metro & 0.6718579 & 0 & 0.9153431 & 1 \\
\hline & density & 1.179039 & 0.0104141 & 2.465241 & 1.009193 \\
\hline \multirow{5}{*}{ (4) } & coast & -0.4872183 & 0 & 0.5723974 & 1 \\
\hline & port & 0.0457353 & 0 & 1.06688 & 1 \\
\hline & urban & 0.1406595 & 0 & 0.9364755 & 1 \\
\hline & metro & 0.6718579 & 0 & 0.9153431 & 1 \\
\hline & density & 1.179039 & 0.0104141 & 2.465241 & 1.009193 \\
\hline \multirow{5}{*}{ (5) } & coast & -0.4872183 & 0 & 0.5723974 & 1 \\
\hline & port & 0.0457353 & 0 & 1.06688 & 1 \\
\hline & urban & 0.1406595 & 0 & 0.9364755 & 1 \\
\hline & metro & 0.6718579 & 0 & 0.9153431 & 1 \\
\hline & density & 1.179039 & 0.0104141 & 2.465241 & 1.009193 \\
\hline
\end{tabular}


Table A6: Balancing conditions for Table 7

\begin{tabular}{|c|c|c|c|c|c|}
\hline & \multicolumn{2}{|c|}{ Standardized differences } & \multicolumn{2}{|c|}{ Variance ratio } \\
\hline & & Raw & Matched & Raw & Matched \\
\hline \multirow{6}{*}{ (1) } & coast & -0.3772586 & 0 & 0.7048681 & 1 \\
\hline & port & 0.2695642 & 0 & 1.161865 & 1 \\
\hline & urban & 0.2182638 & 0 & 0.9010614 & 1 \\
\hline & metro & 0.7677204 & 0 & 0.9380355 & 1 \\
\hline & density & 1.272433 & 0.0384213 & 2.741205 & 1.029075 \\
\hline & gdp_capita & 0.6590686 & 0.0369068 & 3.548327 & 1.122606 \\
\hline \multirow{6}{*}{ (2) } & coast & -0.3749366 & 0 & 0.7058315 & 1 \\
\hline & port & 0.2764176 & 0 & 1.167183 & 1 \\
\hline & urban & 0.2076496 & 0 & 0.9055199 & 1 \\
\hline & metro & 0.7507381 & 0 & 0.9296699 & 1 \\
\hline & density & 1.212686 & 0.0340035 & 2.322464 & 1.050849 \\
\hline & gdp_capita & 0.6572585 & 0.0111534 & 3.573815 & 1.087231 \\
\hline \multirow{6}{*}{ (3) } & coast & -0.3722431 & 0 & 0.7069599 & 1 \\
\hline & port & 0.2791757 & 0 & 1.169363 & 1 \\
\hline & urban & 0.2073006 & 0 & 0.9056704 & 1 \\
\hline & metro & 0.7490661 & 0 & 0.928872 & 1 \\
\hline & density & 1.211658 & 0.0340035 & 2.31902 & 1.050849 \\
\hline & gdp_capita & 0.6540941 & 0.0111534 & 3.587603 & 1.087231 \\
\hline \multirow{6}{*}{ (4) } & coast & -0.3725054 & 0 & 0.7068494 & 1 \\
\hline & port & 0.2789258 & 0 & 1.169164 & 1 \\
\hline & urban & 0.2073369 & 0 & 0.9056546 & 1 \\
\hline & metro & 0.7487705 & 0 & 0.9287314 & 1 \\
\hline & density & 1.211483 & 0.0340035 & 2.318388 & 1.050849 \\
\hline & gdp_capita & 0.6537022 & 0.0111534 & 3.591625 & 1.087231 \\
\hline \multirow{6}{*}{ (5) } & coast & -0.3765156 & 0 & 0.7051762 & 1 \\
\hline & port & 0.2748019 & 0 & 1.165917 & 1 \\
\hline & urban & 0.2091099 & 0 & 0.9048924 & 1 \\
\hline & metro & 0.7517194 & 0 & 0.9301403 & 1 \\
\hline & density & 1.213298 & 0.0340035 & 2.324461 & 1.050849 \\
\hline & gdp_capita & 0.6568173 & 0.0111534 & 3.575619 & 1.087231 \\
\hline
\end{tabular}

Table A7: Balancing conditions for Table 8

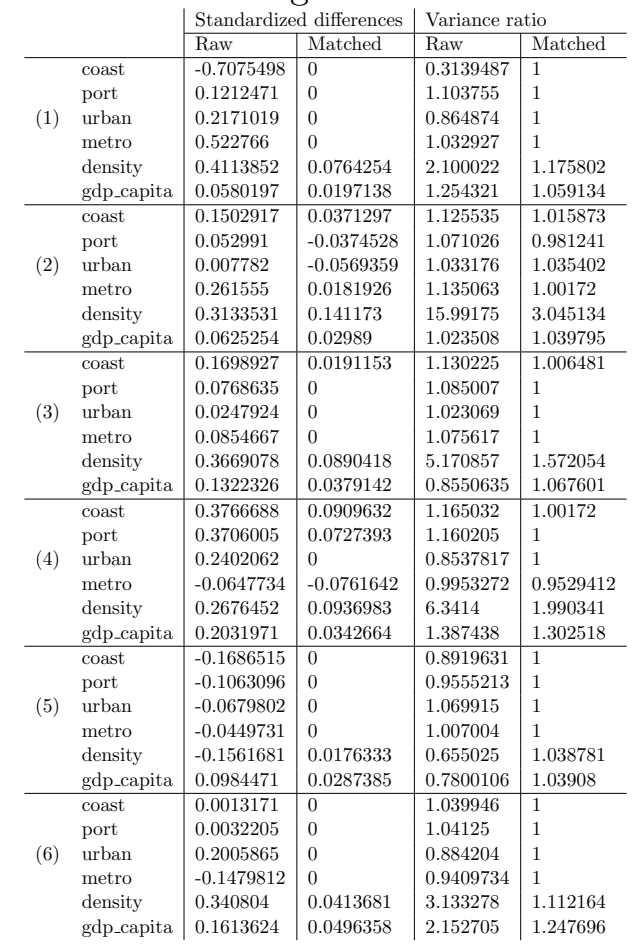

